\title{
ПІДВИЩЕННЯ КОНКУРЕНТОСПРОМОЖНОСТІ ПРОДУКЦІї ФЕРМЕРСЬКИХ ГОСПОДАРСТВ І СІЛЬСЬКОГОСПОДАРСЬКИХ ПІДПРИЕМСТВ ІЯК ОРГАНІЗАЦІЙНО-ЕКОНОМІЧНИЙ ПРІОРИТЕТ ЇХ ФУНКЦІОНУВАННЯ ТА РОЗВИТКУ
}

\author{
Скрипник Світлана Валентинівна \\ кандидат економічних наук, доцент \\ Херсонський державний аграрний університет (м. Херсон, Україна) \\ ORCID: 0000-0003-3004-6117 \\ skrypnik-s@ukr.net
}

У статті визначено конкурентоспроможність продукції як організаційно-економічну пріоритет функціонування та розвитку фрермерських господарств і сільськогосподарських підприємств. Адже від її представлення на аграрних ринках залежать інші конкурентні переваги, стійкість, прибутки тощо. Зазначено, що підвищення конкурентоспроможності продукції передбачає застосування принаймні двох організаційно-управлінських підходів: з орієнтацією на споживачів та з орієнтацією на конкурентів. При цьому важливе значення має досягнення оптимального співвідношення між якістю та ціною продовольчих товарів. Обгрунтовано, що досягнення та збереження й підвищення конкурентоспроможності продукції як організаційно-економічного пріоритету суб'єктів господарювання агробізнесу передбачає оптимізацію та скорочення витрат на її виробництво, продуктивності ресурсокористування, потенціалу розвитку.

Ключові слова: фермерські господарства, сільськогосподарські підприємства, конкурентоспроможність, продукція, організаційно-економічні пріоритети, споживачі, конкуренти, витрати, якість, управління, підвищення.

DOI: https://doi.org/10.32845/bsnau.2019.3.25

Постановка проблеми. Теоретичне уточнення взаємозв'язку основних понять щодо формуванням конкурентних переваг суб'єктів господарювання, має практичну значущість, оскільки дає змогу керівництву вже на початковому етапі створення конкурентних переваг визначити, що брати за основу конкурентної переваги і який результат має бути досягнутий. Слід зазначити, що можливості забезпечення конкурентних переваг залежать від низки факторів. Одним із вирішальних чинників ринкового успіху господарств і підприємств та важливою конкурентною перевагою $€$ співвідношення у системі “ціна - якість продукції". ІЇ̈ досягнення є важливим організаційно-економічним пріоритетом їх розвитку.

Аналіз останніх досліджень і публікацій. Проблеми конкурентоспроможності фермерських господарств і сільськогосподарських підприємств постійно знаходяться у полі зору закордонних та вітчизняних науковців-економістів: Ю. Данька, Л. Євчук, М. Ігнатенка, О. Красноруцького, Н. Мазура, М. Маліка, М. Місюка, О. Шпичака та ін. Предметом їх дослідження є категорії конкуренції, конкурентоспроможності, конкурентних переваг; чинники формування конкурентоспроможності та її складники; напрями досягнення й управлінські рішення щодо підвищення. Проте розуміння конкурентоспроможності як одного з базових організаційно-економічних пріоритетів їх розвитку вимагає подальших розробок.

Формулювання цілей статті. Метою статті є всебічна оцінка конкурентоспроможності продукції фермерських господарств і сільськогосподарських підприємств та обгрунтування джерел і напрямів її підвищення як організаційноекономічного пріоритету їх розвитку.

Виклад основного матеріалу дослідження. Співвідношення ціни й якості продукції є однією з основоположних системних характеристик конкурентоспроможності суб'єктів господарювання агросфери. Якість продукції визначається мірою товарів (робіт чи послуг) відповідати вимогам стандартів та задовольняти потреби споживачів відповідно до їх призначення.

Наразі в умовах мінливої соціально-економічної ситу-

ації в Україні велика перспектива виходу вітчизняних підприємств на європейський та інші міжнародні ринки якісних продовольчих продуктів є дуже актуальною. Для отримання конкурентних переваг підприємствам спочатку потрібно визначитися з підходами, які будуть застосовуватися для цього. Аналіз таких підходів достатньо вичерпно проведено у статті Дж. Дея та Р. Венслі [1]. Ними виділено два основних підходи до отримання конкурентних переваг: підхід, акцентований на споживачах, та підхід, акцентований на конкурентах.

Підхід, акцентований на споживачах, передбачає, що підприємство отримує конкурентні переваги, коли його товари краще, ніж товари конкурентів, задовольняють потреби споживачів. У силу останнього вважається, що цей підхід $€$ більш задовільним із погляду концепції маркетингу. Застосування цього підходу передбачає концентрацію пріоритетів на потребах споживачів, застосування методів, які посилюють об'єктивне та суб'єктивне задоволення споживачів товарами фірми.

На противагу попередньому підхід, орієнтований на конкурентів, заснований на стратегії й тактиці протидії конкурентам. У межах цього підходу можуть використовуватися два способи досягнення конкурентних переваг: лідерство за витратами та сукупність дій із погіршення якості конкурентного середовища [2, с. 68]. Основна відмінність більшості вітчизняних аграрних підприємств, особливо малих і середніх, від їм подібних закордонних та конкурентів полягає у тому, що вони на порядок чи у кілька разів менш ефективні й капіталомісткі. Відповідно, для формування власних конкурентних переваг необхідно або вкладати в розвиток стільки ж ресурсів, скільки вкладають закордонні конкуренти, що дуже проблематично, або концентрувати свої ресурси тільки на найбільш пріоритетних перспективних напрямах діяльності.

Стрімке підвищення рівня конкуренції на внутрішньому і зовнішніх ринках призводить до того, що в найближчій перспективі конкурентоспроможними будуть ті господарства і підприємства, які матимуть конкурентні переваги в усіх сфеpax, a саме: у зниженні витрат, поліпшенні якості та розши- 
ренні асортименту продукції; забезпеченні гнучкості виробництва; підвищенні рентабельності; впровадженні інновацій; розвитку знань тощо [3, с. 29]. Конкурентні переваги на рівні суб'єктів господарювання агросфрери залежать від конкурентних переваг їх продукції (робіт чи послуг), а саме якою мірою продукція задовольняє вимоги споживачів. Конкурентна перевага продукції, своєю чергою, визначається шляхом зіставлення якості, яка відповідає певним вимогам, із ціною на дану продукцію та ін.

Ефективне функціонування фермерських господарств і сільськогосподарських підприємств залежить від того, наскільки швидко вони зможуть сконцентрувати свої зусилля для виробництва продукції високої якості із забезпеченням найменших витрат, найбільшої кількості, з ефрективним використання ресурсів та встановлення вдалої ціни для споживача. Передусім, для цього потрібно співставити ви- моги ринку виробників із вимогами ринку споживачів. Виходячи із цього, за рахунок стимулювання всіх виробничих підрозділів та їх працівників у напрямі підвищення якості продукції, а також поєднання потрібних вимог ринку щодо якісних характеристик, показників якості, ціни та часу формуються конкурентні переваги.

Конкурентні переваги, як стратегічні чинники організаційно-економічних пріоритетів розвитку фермерських господарств і сільськогосподарських підприємств, повинні відповідати таким вимогам: 1) базуватися на їх можливостях, які зобов'язані бути оригінальнішими порівняно з конкурентами і які неможливо або важко скопіювати; 2) забезпечувати унікальність торгової марки (бренду) порівняно з конкурентами у довгостроковій перспективі; 3) задовольняти специфічні потреби споживачів. Доцільно виокремити критерії оцінки та аналізу конкурентних переваг суб'єктів господарювання агросфери (рис. 1).

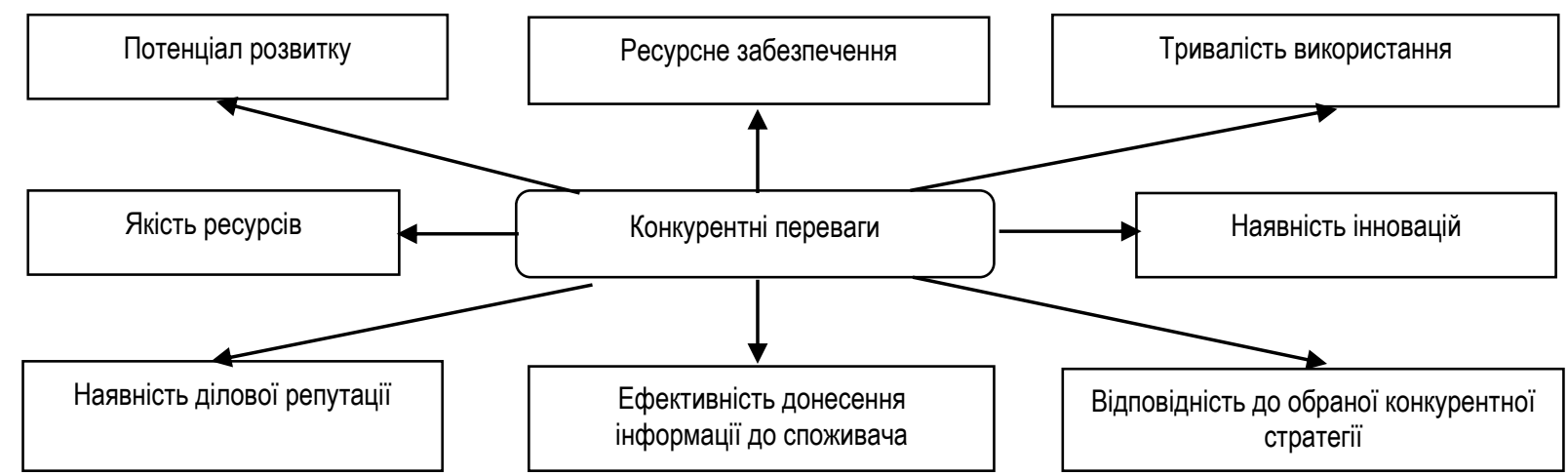

Рис. 1. Критерії оцінки конкурентних переваг суб'єктів господарювання агросфери

Конкурентні переваги виникають і виявляються тоді і там, де виникає і розвивається конкуренція. Це означає, що чим більш всеосяжного характеру набуває конкуренція, тим більш значущими для успіху на аграрному ринку, в господарській діяльності окремих господарств і підприємств, сфрер діяльності стають їх конкурентні переваги [4, с. 162]. Термін «конкуренція» походить від латинського дієслова concurrere, яке у буквальному перекладі означає «збігатися», а у переносному значенні - «суперничати, змагатися». Тобто, «конкуренція - це економічне змагання за досягнення кращих результатів у будь-якій діяльності, боротьба товаровиробників за найбільш вигідні умови господарювання, одержання максимального прибутку».

Комплексний підхід передбачає врахування теоретичних і методологічних позицій і засад поведінкового, структурного й функціонального підходу. Тим самим, він є максимально всеохоплюючим у визначенні конкуренції як економічного явища та процесу, що забезпечує мотивацію суб'єктів до формування конкурентоспроможності. Саме комплексний підхід потрібно вважати актуальним для сучасної практики, бо він дає можливість урахувати зокрема аспекти дії глобального ринку.

У теоретичному плані слід звернути увагу на галузеві особливості характеристик визначень конкуренції, зокрема в нашому випадку стосовно сільського господарства - галузі із сезонним характером виробництва. Вітчизняні сучасники, а також дослідники проблем сільськогосподарського ринку й аг- рарного підприємництва здебільшого дотримуються функціонального та поведінкового підходу з урахуванням ознак комплексного. За їхнім визначенням, конкуренція - це: економічний закон боротьби підприємств за виживання (О. Красноруцький) [5]; ефективний метод економічного контролю за бізнес-процесами (М. Ігнатенко) [6]; за витратами виробництва (Ю. Данько) [5].

Вважаємо, що така багатоманітність, різноаспектність визначень конкуренції пов'язана з її присутністю в усіх ссрерах суспільної та економічної (ринкової діяльності). Ми ж схиляємося до визначення, що конкуренція - це, перш за все, функція ринку й спосіб досягнення цілей підприємницької діяльності. На базі зазначеного в аналізі теоретико-методичних конструкцій поняття «конкуренція» доцільно зробити висновок про те, що вихідною умовою конкуренції $€$ конкурентоспроможність - якісні ознаки суб'єкта або ж об'єкта конкуренції, які дозволяють йому забезпечувати реалізацію стратегії економічної боротьби.

Таким чином, головною умовою успішної конкуренції суб'єктів підприємницької діяльності в агросфрері за ринки, товари, послуги, споживача є сформований ними рівень конкурентоспроможності. Конкурентоспроможність - одна з головних умов успішного ведення агробізнесу, конкурентного функціонування господарств і підприємств на ринку. Це специфічно виражено в сільськогосподарській господарсько-економічній та збутовій системі. В ній суб'єкти господарювання постійно відчувають вплив інших, які реалізують аналогічну про- 
дукцію на ринку, бо в класичному розумінні - це ринок із чистою конкуренцією.

Відтак, конкурентоспроможність фермерських господарств і сільськогосподарських підприємств формується під впливом багатьох суб'єктивних та об'єктивних чинників. Цей процес $€$ цілком природним щодо аграрного бізнесу в світі, відповідно і в Україні. Виявлення та примноження переваг, властивих йому, уможливлює конкурентоспроможний розвиток на засадах застосування потенціалу стратегічного менеджменту та фрінансово-економічного інструментарію [7, с. 15]. Для виявлення стану конкурентоспроможності господарств підприємств та його аналізу необхідно врахувати такі компоненти:

- результативність використання основних засобів виробництва (забезпечувальна роль основних засобів виробництва), нарахування амортизації, використання амортизаційного фонду, відтворення;

- стан технологічності виробничих процесів (забезпечувальна роль технології виробництва), впровадження інновацій;

- інфрормаційна узгодженість та доступність (вплив інформаційних ресурсів);

- застосування технічного потенціалу та технічних новацій (забезпеченість технічними новаціями);

- рівень стану кадрового забезпечення (наявність та результативність діяльності працівників, фрахівців, менеджерів);

- фінансово-економічна стійкість та фінансово-економічний потенціал діяльності;

- інноваційно-інвестиційна діяльність та привабливість (забезпеченість та використання інвестиційних ресурсів та реалізація інноваційних заходів у діяльності);

- досягнення конкурентних переваг та утримання конкурентних позицій на аграрних ринках (вартість бренду, рівень капіталізації та ін.);

- поширення знань, технологій та інформації за участю аграрної науки, освіти та суб'єктів дорадчої діяльності, для створення ефективної системи безперервної аграрної освіти, наукового обслуговування сільськогосподарського виробництва та їх конкурентоспроможного розвитку.

Попри наявні позитивні євроінтеграційні тенденції подальшого функціонування великих підприємств аграрної галузі України, для утримання конкурентоспроможних позицій на європейському ринку та адекватного фінансового забезпечення конкурентоспроможної діяльності всіх сільськогосподарських підприємств необхідно сконцентруватись на таких напрямах діяльності:

- формування достатнього обсягу фінансових та інвестиційних ресурсів відповідно до пріоритетів і стратегії розвитку;

- забезпечення стратегічної структури фінансових та інших ресурсів;

- оптимізація виробництва і площ земельних ресурсів;

- прискорення модернізації виробництва і поліпшення якості та сертифікації продукції у відповідності до вимог і стандартів ЄС;

- ефективне використання активів у розрізі пріоритетних напрямів діяльності;

- інвестування в об'єкти інфраструктури та біоенергетики
- соціальна відповідальність бізнесу та сприяння розвитку малих і середніх сільськогосподарських підприємств.

Реалізація вищенаведених мікроекономічних чинників фінансово-економічного забезпечення конкурентоспроможності фермерських господарств і сільськогосподарських підприємств буде можливою тільки за умови створення відповідного макросередовища конкурентоспроможного розвитку національної економіки [8, с. 29]. Важливого значення набувають такі макроекономічні чинники фрінансово-економічного забезпечення конкурентоспроможності:

- формування інноваційної моделі національної економіки, яка полягає у переході від галузей індустріальної епохи до цифрової, що означає високотехнологічне, ресурсозберігаюче, агропромислове виробництво й переробка, машинобудування, інформаційно-комунікаційні технології, спеціалізований транспорт і зберігання тощо;

- розробка та реалізація тренінгів - очних та онлайн з бізнес-планування, маркетингу, зовнішньоекономічної діяльності, управління інноваціями та інвестиціями;

- інтенсифікація виробництва одночасно з органічним рухом;

- оздоровлення інвестиційного клімату через системне вдосконалення нормативно-правової бази, ліквідацію корупції, тіньової економіки;

- виважена монетарна політика, удосконалення банківської і фінансової системи загалом з умовою кредитування суб'єктів малого і середнього агробізнесу, їх бюджетної підтримки;

- впровадження систем екологічного менеджменту, екологічної сертифрікації та екологічного маркування продукції згідно з вимогами міжнародних стандартів;

- встановлення єдиних державних вимог щодо безпеки та якості продуктів харчування та підвищення рівня ділової досконалості підприємців;

- розвиток законодавства у сфері конкуренції та інститутів ринку у відповідності з європейськими стандартами та практикою з метою зниження рівня монополізації економіки та стимулювання розвитку малого і середнього підприємництва в аграрній ссрері.

В умовах цифрової економіки, економіки знань, які впроваджуються у всі сфери суспільної життєдіяльності важливе значення має захист прав інтелектуальної власності. Він стимулюватиме інновації, пришвидшить соціально-економічний розвиток та сприятиме: активізації трансферу технологій, який дасть можливість підвищення рівня конкурентоспроможності аграрних підприємств, у тому числі суб'єктів малого і середнього підприємництва; забезпеченню конкурентоспроможності на базі оптимізації енерго- й ресурсоспоживання, що визначатиметься глибиною наукового пророблення конкретних завдань, комплексністю дій суб'єктів господарювання; дотриманню державних і міжнародних екологічних стандартів, норм, обмежень, що буде зумовлене підвищенням рівня конкурентоспроможності, зниженням виробничих витрат для отримання прибутків від організації нетрадиційних джерел енергії, переробкою відходів, біологічними меліораціями тощо [9, с. 14].

Зазначені інституції дозволяють прискорити розвиток інноваційно-інвестиційних проектів забезпечення організаційно-економічних пріоритетів фермерських господарств і сільськогосподарських підприємств незалежно від стадії, на 
якій він перебуває. Такий результат досягається через розробку й доступ стартапів до технологій, знань, інфраструктури та капіталу, який створюють бізнес-акселератори. У створення такої інфрраструктури власні кошти та час інвестує, переважно, великий агробізнес. Основною метою при цьому $є$ продукти або технології, які можна застосувати в своїй роботі, або отримання їхньої частки в перспективному стартапі.

Для оцінки ефективності бізнес-планів, інноваційно-інвестиційних проектів і стартапів залучаються експерти - фахівці. Групи експертів формують власники сільськогосподарських підприємств, топ-менеджмент та менеджери структурних підрозділів, спеціалісти фінансового та економічного напрямів, які формуються на таких засадах: досвід роботи в аграрному бізнесі або володіння сільськогосподарським підприємством, наявність фахової освіти, професійних компетентностей спеціаліста в аграрній сфрері; досвід роботи в системі маркетингу та наявність відповідної освіти; досвід роботи в фінансових інституціях та аналітичні здібності; бажання прийняти участь в діяльності експертної групи.

Основоположними сегментами системного управління визначені: ідентифікація галузевого середовища, управління конкурентоспроможністю видів продукції, управління конкурентоспроможністю господарств і підприємств. Для реалізації місії зазначених сегментів необхідним є відповідне економічне і фінансове забезпечення конкурентоспроможності. Функціональна фінансово-економічна гармонізація підвищення конкурентоспроможності має ірунтуватися на процесових та системних засадах.

Процесові засади реалізуються через застосування ресурсного потенціалу господарств і підприємств, що представлений сукупністю матеріальних, фінансових, інформаційних, трудових ресурсів. Використання ресурсів спрямовується на досягнення соціально-економічної мети функціонування та отримання позитивної фрінансової результативності. Системні засади втілюються шляхом взаємодії пов'язаних компонентів, що спрямовані на уможливлення досягнення найкращих результатів функціонування зазначеної системи.

Функціональна фінансово-економічна гармонізація конкурентоспроможності фермерських господарств і сільськогосподарських підприємств презентується як система взаємодії ресурсного потенціалу і процесу відтворення, системне управління якої забезпечується використанням наявного теоретико-методологічного й практичного інструментарію 3 урахуванням чинників, методів й способів їх зв'язку та залежностей, що уможливлюють максимізацію результативного прояву.

При цьому однією з ключових проблем розвитку сільськогосподарського підприємництва в Україні на різних рівнях залишається практична відсутність довготермінового планування та управління з ефективною координацією діяльності усіх ланок, які зайняті у процесі аграрного відтворення, тобто відсутність базового аналізу конкурентних переваг на ринку і відсутність успішного стратегічного управління. Стратегічне управління - мистецтво і наука розробки, впровадження й оцінки крос-функціональних рішень, які дадуть змогу організації досягти своїх цілей. Отже, як випливає з цього визначення, стратегічний менеджмент зосереджується на інтеграції менеджменту, маркетингу, фінансів, виробництва, наукових досліджень, а також інформаційної системи для досягнення організаційно-економічних пріоритетів розвитку фермерських господарств і сільськогосподарських підприємств
$[10$, c. 198].

Якщо у сільськогосподарських підприємствах системне управління, у т.ч. стратегічне впроваджується, то у фермерських господарствах планування з елементом стратегічного управління практично відсутнє. Водночас, практично не враховуються конкурентні переваги, які мають представники цього виду підприємницької діяльності. Тому для фермерських господарств країни під ними слід розуміти наявність інноваційної операційної діяльності, метою якої є отримання унікальної продукції з особливими якостями та характеристиками порівняно з іншими сільськогосподарськими товаровиробниками, що має високий попит серед споживачів як на внутрішньому, так і на зовнішньому ринках.

У широкому розумінні конкурентні переваги вітчизняного агросектору визначаються як найкращі властивості суб'єктів господарювання або їх діяльності відносно інших на місцевому, галузевому, міжгалузевому, регіональному, національному, глобальному рівнях. Найчастіше мова йде про велике землезабезпечення, природну родючість ґрунтів, сприятливі агрокліматичні умови, значні меліоративні системи та мережі, велику розораність території, кваліфіковані трудові ресурси, інновації, масштабне органічне виробництво, значний довід господарювання, високий рівень корпоратизації й капіталізації виробництва, високоякісну й дешеву продукцію.

Саме вони розуміються як джерела здійснення організаційно-економічних пріоритетів розвитку фермерських господарств і сільськогосподарських підприємств. Проте вони можуть вступати у протиріччя одне з одним, бути різними в різних регіонах, мати різні й неоднозначні механізми та інструменти впровадження, ефективність використання, доступність різним формам господарювання, що вимагає врахування та обачного їх залучення.

Поряд з конкурентними перевагами, доцільно розглянути й оцінити недоліки, ризики, чинники невизначеності у розвитку фермерських господарств і сільськогосподарських підприємств, які можна розцінювати не тільки як несприятливі фактори, але й спонукальні мотиви для здійснення тих або інших його організаційно-економічних пріоритетів. Серед них необхідно вказати на розміщення значних площ сільськогосподарських угідь у зонах ризикованого землеробства; наявність непередбачуваних погодно-кліматичних явищ; згортання тваринництва; значні сезонні коливання попиту і пропозиції на внутрішньому аграрному ринку;різка відмінність у прибутках, технологіях, продуктивності праці, присутності на ринку між агрохолдингами й іншими формами господарювання; вивільнення значної кількості працівників, збідніння сільського населення, соціальна напруженість на селі.

Об'єктивно, фермерські господарства й сільськогосподарські підприємства мають різний конкурентний потенціал для здійснення організаційно-економічних пріоритетів розвитку, як і інші мотиви. Це стосується ресурсів та їх забезпечення, умов виробництва й збуту готової продукції, використання трудових ресурсів, впровадження інновацій та цисровізації, реєстрації і оподаткування, рівня участі у вирішенні соціально-економічних проблем села і розвитку сільських територій. При цьому найбільші протиріччя спостерігаються між фермерськими господарствами й великими агрохолдингами.

Понад 44,6 тис. фермерських господарств зосереджують 4437,9 тис. га земель та виробляють 8,7 \% сільськогосподарської продукції. Великі агрохолдинги у кількості 853 
площею аграрного землекористування понад 5,6 млн. га. забезпечують виробництво 21,2 \% продукції та основну частину валютних надходжень від експорту продукції. Проте зареєстровані переважно в офшорах, вони не сплачують належні податки у бюджет та не беруть участі у вирішенні проблем розвитку сільських територій, об'єктів соціальної інфраструктури й житлово-комунального господарства, на відміну від фермерських господарств.

Висновки. Отже, навіть правильно обрані пріоритети розвитку можуть мати негативні наслідки за відсутності належного державного регулювання й контролю. Особливо це стосується соціальних та екологічних аспектів розвитку великотоварного виробництва. Зокрема, успішна діяльність агрохолдингів сприяла проявам безробіття, різкого соціального розшарування сільського населення, його бідності; погіршення доступу до суспільних благ. Також це згортання соціальної інфраструктури й житлово-комунального господарства; ігнорування природоохоронних заходів і необхідності відтворення природних ресурсів сільських територій. Фермерські господарства також не завжди займають правильні ринкові ніші виробництва і збуту продукції; не мають доступу до пе- редових технологій; фрінансових можливостей для забезпечення власної стійкості та допомоги односельцям.

Повільному усуненню і навіть збереженню виявлених негативних тенденцій сприяє недостатня за обсягами й недосконала за структурою державна політика підтримки, стримування й обмежень в агросекторі; моніторинг, контроль і відповідні заходи щодо діяльності агроутворень; відсутність системного навчання й перепідготовки кадрів для села на інноваційних засадах; слабкість сільських територіальних громад як інститутів влади та організації життєдіяльності на селі.

Мова йде й про недостатній розвиток інших інструментів регулювання та підтримки: державно-приватного партнерства; товарного кредитування й кредитних спілок; обслуговуючих та споживчих кооперативів; соціальної відповідальності всіх підприємств агробізнесу; громадських організацій та фондів на селі. Радикальна реформа організації сільських територій з їх укрупненням має наслідком не тільки зменшення адміністративних витрат, але й доступності сільських жителів до суспільних благ, втрату центрів організації території та їх збереження загалом за відсутності добре розвиненої мережі шляхів сполучення. Це треба враховувати у перспективі її здійснення.

\section{Список використаної літератури.}

1. Wensley R. Assessing Advantage: A Framework for Diagnosing Competitive Superiority. Journal of Marketing. 1988. April. Vol. 52. P. 65-72.

2. Шубравська О.В., Прокопенко К.О. Інтеграційні перспективи України: переваги і ризики для аграрного сектору. Економіка України. 2014. № 1. С. 63-73.

3. Драган О.І. Управління конкурентоспроможністю підприємств: теоретичні аспекти: монографія. К.: ДАКККіМ. 2006. $160 \mathrm{c}$.

4. Мандич О.В., Романюк I.А., Нікітіна О.M. PR-маркетинг як один з інструментів підвищення конкурентоспроможності підприємства. Вісник ХНТУСГ : економічні науки. Вип. 177. 2016. С. 160-165.

5. Красноруцький О.О., Данько Ю.І. Розвиток маркетингу на ринку агропродовольчої продукції України : монографія. Х. : Міськдрук, 2009. 262 с.

6. Ігнатенко М.М., Рунчева Н.В. Процеси ресурсозабезпечення спеціалізації та концентрації виробництва в корпоративних агроформуваннях. Економіка та держава. № 1. 2017. С. 10-14.

7. Молдаван Л.В. Форми господарювання в аграрному секторі України в умовах глобалізації. Економіка АПК. 2010. № 1. C. 13-17.

8. Мармуль Л.О., Жуйков Г.Є., Волович С.В. Методичні засади дослідження фермерських та особистих господарств в АПК регіону. Матеріали міжнар. наук. теор. конф. "Методичні основи сучасного дослідження в аграрній економіці". Житомир: Вид-во “Державний агроекологічний університет", 2005. Ч. 2. С. 28-30.

9. Мазур Н.В., Місюк М.В. Конкурентоспроможність виробництва сільськогосподарської продукції та основні напрями ії підвищення. Економіка АПК. 2007. № 2. С. 12-16.

10. Євчук Л.А. Стратегічне управління конкурентоспроможністю сільськогосподарських підприємств : монографія. Миколаїв : Вид-ць Прокопчук Т. Ю., 2010. 340 с.

Skrypnyk S.V., PhD, Associate Professor, Kherson State Agrarian University (Kherson, Ukraine)

Improving the competitiveness of farm products and agricultural enterprises as an organizational and economic priority for their functioning and development

The article defines the competitiveness of products as an organizational and economic priority for the functioning and development of farms and agricultural enterprises. After all, other competitive advantages, stability, income, and so on depend on its representation in agricultural markets. It is noted that increasing the competitiveness of products involves the use of at least two organizational and managerial approaches: consumer-oriented and competitor-oriented. At the same time, it is important to achieve an optimal ratio between the quality and price of food products. It is proved that achieving and maintaining and improving the competitiveness of products as an organizational and economic priority of agribusiness entities involves optimizing and reducing the cost of its production, resource use productivity, and development potential.

Key words: farms, agricultural enterprises, competitiveness, products, organizational and economic priorities, consumers, competitors, costs, quality, management, improvement.

Дата надходження до редакції: 29.08.2019 p. 